\title{
APPLICATION PERFORMANCE ASSESSMENT WORK USING SIMPLE ADDITIVE WEIGHTING (SAW) METHOD
}

\author{
${ }^{(*) 1}$ Tias Ambarwati, ${ }^{2}$ Fajar Masya \\ 1,2 Information Systems Study Program, Universitas Mercu Buana Jakarta \\ www.mercubuana.ac.id \\ email: ${ }^{1}$ tiasambarwati@gmail.com, ${ }^{2}$ fajar.masya@mercubuana.ac.id
}

$\left(^{*}\right)$ Corresponding Author

\begin{abstract}
Abstrak
Penanganan Prasarana dan Sarana Umum (PPSU) adalah petugas yang dibentuk tahun 2015 oleh Basuki Tjahaja Purnama Gubernur DKI Jakarta di Tingkat Kelurahan. Penilaian yang dilakukan oleh Kelurahan Munjul pada saat ini masih dilakukan secara subjektif oleh Kepala Seksi Ekonomi dan Pembangunan dan tidak ada parameter yang jelas dan terperinci dalam menentukan penilaian pekerja. Sehingga dapat mengakibatkan tidak transparannya penilaian kinerja PPSU. Penerapan sistem pendukung keputusan dalam penilaian prestasi kerja PPSU akan memberikan penilaian secara terstruktur. Salah satu metode yang dapat dipakai dalam sistem pendukung keputusan adalah Simple Additive Weighting (SAW). Konsep metode ini adalah dengan mencari rating kinerja (skala prioritas) pada setiap alternatif disemua atribut. Perhitungannya dapat menentukan PPSU terbaik dengan akurat guna pengambilan keputusan perekrutan PPSU setiap tahunnya.
\end{abstract}

Kata kunci: Prestasi Kerja, Penanganan Prasarana dan Sarana Umum, Simple Additive Weighting (SAW), Sistem Pendukung Keputusan

\begin{abstract}
Handling Infrastructure and Public Facilities (PPSU) are officers formed in 2015 by Basuki Tjahaja Purnama, the Governor of DKI Jakarta at the Kelurahan level. The assessment carried out by Munjul Kelurahan is currently still subjectively subject to a section by the Head of the Economy and Development Section and there are no clear and detailed parameters in determining workers' assessments. So that it can result in non-transparent PPSU performance evaluation The application of decision support systems in the assessment of PPSU work performance will provide a structured assessment. One method that can be used in decision support systems is Simple Additive Weighting (SAW). The concept of this method is to look for a performance rating (priority scale) on each alternative in all attributes. The calculation can determine the best PPSU accurately to make PPSU recruitment decisions every year.
\end{abstract}

Keywords: Job Performance, Public Infrastructure and Facilities Management, Simple Additive Weighting (SAW), Decision Support System

\section{INTRODUCTION}

Handling Infrastructure and Public Facilities (PPSU) is an officer handling 2015 by Basuki Tjahaja Purnama, the Governor of DKI Jakarta at the Kelurahan level. The main tasks of the PPSU are divided into 3 parts, namely the management of road infrastructure and facilities, the management of channel facilities and infrastructure, and the management of park infrastructure and facilities. PPSU is included in the Other Individual Service Providers (PJLP) who are recruited by the Lurah with a contract system every year following Governor Regulation No. 125 of 2019 (Baswedan, 2019). There are 56 PPSUs in Kelurahan Munjul. The Head of the Economy and Development Section assessed it subjectively (Frieyadie, 2018)(Rihastuti et al., 2019) due to the absence of parameters (Putri, 2018) in the detail that was made, the evaluation was impressed as he pleased the appraiser (Agustini \& Ariska, 2019). It is expected that with the assessment following the criteria outlined in the Governor's Regulation and the weight that has been determined by the Kelurahan Munjul, the PPSU assessment can be more transparent and accurate. 
Work performance appraisal is a process through which organizations evaluate or assess employee work performance. Performance appraisal is a process of evaluating employee work performance carried out by the organization to its employees systematically and formally based on the work assigned to it (Bintoro \& Daryanto, 2017).

Decision Support System is a specific information system intended to assist management in making decisions (Latif et al., 2018) relating to issues that are semi-structured. This system has facilities to produce various alternatives that are interactively used by users (Nofriansyah \& Defit, 2017).

The adoption of a decision support system in evaluating PPSU work performance will provide a structured assessment, which will assist the head of the Economy and Development Section in evaluating PPSU performance so that the decision will be stronger because it is supported by a detailed assessment system. Likewise, workers who are judged to be more satisfied and accept the decision of the Head of the Economy and Development Section. This study uses the SAW method, this method has been applied by other researchers as follows:

The first researcher explained that at the University of Lampung there were problems in the selection of outstanding lecturers in the University of Lampung (Unila) environment, the assessment process for outstanding lecturers was still done manually and the assessment was subjective. The purpose of this research is to create a decision support system for the assessment of outstanding lecturers using the Simple Additive Weighting (SAW) method, with criteria (C1) Superior Prestigious Works; (C2) Teaching; (C3) Dedication; (C4) Support. By doing an assessment using the Simple Additive Weighting (SAW) method, it can solve the problem of determining outstanding lecturers as needed (Kurniawan et al., 2015).

The second researcher explained that at PT Alfaria Trijaya Resources Tbk Malang branch there were problems in recruiting and evaluating warehouse employees. The purpose of this research is to apply a decision support system to select and assess employees so that they can be more selective in selecting and assessing employees using the Simple Additive Weighting (SAW) method, with criteria for recruitment being (C1) Academic value; (C2) Test scores; (C3) Value of physical condition; (C4) The value of the interview. The criteria for employee appraisal are (C1) Value of service; (C2) The value of innovation; (C3) Value of the work; (C4) The value of teamwork; (C5) Behavioral value. By doing an assessment using the method of Simple Additive Weighting (SAW) can choose prospective warehouse employees following the desired criteria and to provide appreciation with the form of assessment to warehouse employees (Agus et al., 2017).

The third researcher explained that at STMIK-IM Bandung there were problems in lecturer performance appraisal activities, in this case, lecturer performance appraisals were assessed from students using a questionnaire. Assessment of lecturers' performance uses the Simple Additive Weighting (SAW) method, with criteria (C1). Lecturers always have material; (C2) The lecturer allocates time for discussion; (C3) Teaching materials to supplement the material; (C4) Provide an objective test score; (C5) Lecturers always arrive on time; (C6) Provide a lecture syllabus; (C7) The lecturer masters the material. The purpose of this study is to make an application for student assessment of the teaching and learning process of lecturers so that it becomes an alternative solution in the process of assessing lecturer performance (Moch.Ali \& Chandra, 2018).

The fourth researcher explained that verifying loan applications at the Mercu Buana Cooperative was still done manually. The purpose of this research is to design a loan application information system for members. With criteria (C1) loan amount; (2) Clean salary; (C3) Kopkar money loans; (C4) Kopkar goods loans; (C5) Bank loans; (C6) Store debt; (C7) Staffing status. The submission of the SAW method can make it easier for cooperatives to determine loan recipients. The existence of information systems can help in managing incoming data (Widyastuti \& Kurnianda, 2019).

The fifth researcher explained that PT. Harjamukti Jaya Mandiri in determining employee decisions with good performance to get salary bonuses (Sukanto, 2018). There are 5 criteria used to measure employee performance, namely (C1) work discipline; (C2) latest education; (C3) work experience; (C4) cooperation; (C6) activity. The results of the study with the Simple Additive Weighting model are expected to help PT. Harjamukti Jaya Mandiri in objectively determining good employee performance (Sukanto, 2018).

The sixth researcher explained that the employee performance appraisal at PTPN XII Malangsari Plantation was still done manually and subjectively. The criteria used in the assessment are the value (C1) of Integrity; (C2) Commitment (C3) Discipline; (C4) Cooperation; (C5) Innovative; (C6) Leadership. This application increases efficiency and helps speed up data processing 
which usually still requires a lot of manual processes so that with limited resources capable of producing something optimal (Setya \& Kom, 1994).

\section{RESEARCH METHODS}

The method used in this study is Simple Additive Weighting (SAW). The concept of this method is to look for a performance rating (priority scale) on each alternative in all attributes (Nofriansyah \& Defit, 2017). The algorithm for solving this method are (1) Define the criteria that will be used as a benchmark for solving the problem; (2) Normalize each alternative value on each attribute by calculating the performance rating value; (3) Calculating the value of preference weights for each alternative; (4) gritting. The formula used to normalize each altering is as follows:

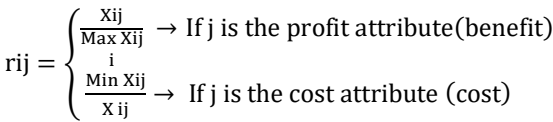

Description:

$\mathrm{r}_{\mathrm{ij}}=$ normalized performance rating

$\operatorname{Max}_{\mathrm{ij}}=$ maximum value of each row and column

Minij = minimum value of each row and column

$\mathrm{X}_{\mathrm{ij}}=$ row and column

The formula for calculating preference weight values for each alternative is as follows:

$V_{I}=\sum_{j=1}^{n} W j r i j$

Description:

$\mathrm{Vi}=$ Weight Preference Value of each alternative

$\mathrm{Wj}=$ Criteria Weight Weight

Rij = Value Rating Performance

The study was conducted on the Handling of Infrastructure and Public Facilities in Kelurahan Munjul, East Jakarta. Collection techniques carried out are by (1) Making observations to the Kelurahan Munjul to see directly the system that runs there; (2) Conducting interviews with the Head of the Economy and Development Section who is in charge of PPSU officers directly; (3) Literature studies such as reading books, journals, information data articles originating from the internet. The research process through the following stage of Paga Figure 1:

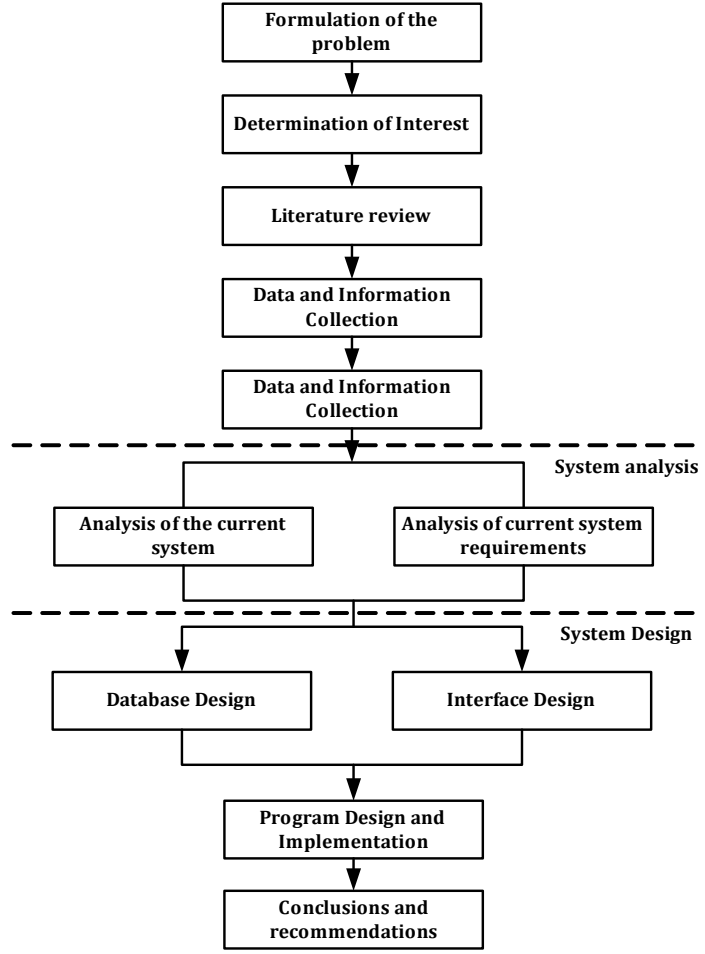

Figure 1 Research Flow Diagram

Explanation of the research flow diagram of Figure 1 above, as follows (1) The formulation of the problem is the initial stage based on the background that exists in the PPSU of Kelurahan Munjul, East Jakarta; (2) Goal setting is the second stage, so that the existing problems get the right and accurate solutions; (3) Literature study is the stage where looking for information from books, journals, articles etc. (4) Collecting data and information by collecting data related to performance appraisal criteria, PPSU data as alternative data generated from observations and interviews; (5) Analysis of the current system to determine the current running process and analysis of system requirements while determining the SPK method in accordance with the PPSU Job Performance Assessment; (6) System design is database design and interface design; (7) The design of the program is related to the system's input and output design and implementation to the user; (8) The final stage of conclusions is conclusions generated from research.

\section{RESEARCH RESULTS AND DISCUSSION}

In determining the assessment of PPSU work performance using the Simple Additive Weighting (SAW) method is to determine the weights on the criteria: 
Table 1 Weight of Criteria

\begin{tabular}{clccc}
\hline Criteria & \multicolumn{1}{c}{ Description } & $\begin{array}{c}\text { Weight } \\
\%\end{array}$ & W & Benefit \\
\hline C1 & $\begin{array}{l}\text { Discipline of } \\
\text { Presence }\end{array}$ & 40 & 0,40 & $\max$ \\
C2 & $\begin{array}{l}\text { Responsibility } \\
\text { for Completion } \\
\text { of Work } \\
\text { Compliance } \\
\text { with Obligations } \\
\text { and } \\
\text { Prohibitions }\end{array}$ & 30 & 0,30 & $\max$ \\
& & 0,30 & $\max$ \\
& & & & \\
\hline
\end{tabular}

Table 1 above explains the criteria that will be used as decision making, weighing, and determination of benefits that will be used in the calculation of SAW.

Tabel 1 Alternatif

\begin{tabular}{ccc}
\hline No & Alternatif & Name \\
\hline 1 & A1 & Epih Gunaeti \\
2 & A2 & Sapri \\
3 & A3 & Farhan Syadidan \\
4 & A4 & Deddy Ramdani \\
5 & A5 & Abdul Rahman \\
\hline
\end{tabular}

Table 2 above explains alternative examples of PPSU data used as data to assess PPSU achievements.

Table 3 Attendance Discipline Parameters

\begin{tabular}{clcc}
\hline No. & $\begin{array}{c}\text { Presence of Discipline } \\
\text { Parameters }\end{array}$ & Range & Weight \\
\hline 1 & 0 minute delay & 100 & 100 \\
2 & $\begin{array}{l}\text { Delay in 1- 10 } \\
\text { minutes }\end{array}$ & $90-99.99$ & 80 \\
3 & 11-20 minutes late & $80-89.99$ & 60 \\
4 & 21-30 minutes late & $75-79.99$ & 40 \\
5 & Delay $\geq 30$ minutes & $<74.99$ & 20 \\
\hline
\end{tabular}

Table 3 above explains the Discipline of Attendance (C1) with the range and weight of the assessment agreed upon by Munjul District.

Table 4 Job Responsibility Parameters

\begin{tabular}{clcc}
\hline No. & $\begin{array}{c}\text { Job Responsibility } \\
\text { Parameters }\end{array}$ & Range & Bobot \\
\hline 1 & Very good & $91-100$ & 100 \\
2 & Well & $81-90.99$ & 80 \\
3 & Enough & $75-80.99$ & 60 \\
4 & Less & $50-74.99$ & 40 \\
5 & Very less & $<49.99$ & 20 \\
\hline
\end{tabular}

Table 4 above explains the Job Completion Responsibility (C2) with the range and weight of the assessment agreed upon by Kelurahan Munjul.
Table 5. Compliance Parameters to Obligations and Prohibitions

\begin{tabular}{llcc} 
No. & $\begin{array}{c}\text { Parameter of } \\
\text { Compliance with } \\
\text { Obligations and } \\
\text { Prohibitions }\end{array}$ & Range & Weight \\
& Very good & $91-100$ & 100 \\
\hline 1 & Well & $81-90.99$ & 80 \\
2 & $75-80.99$ & 60 \\
3 & Enough & $50-74.99$ & 40 \\
4 & Less & $<49.99$ & 20 \\
5 & Very less & & \\
\hline
\end{tabular}

Table 5 above explains Compliance with Obligations and Prohibitions (C3) with the range and weight of the assessment agreed upon by Kelurahan Munjul. As an example of the calculation after the performance appraisal is obtained the following scores:

Table 6 Rating Scores

\begin{tabular}{|c|c|c|c|c|c|}
\hline \multirow[b]{2}{*}{ NO } & \multirow[b]{2}{*}{ Name } & \multicolumn{4}{|c|}{ Criteria } \\
\hline & & $\begin{array}{l}\text { Discipline } \\
\text { of } \\
\text { Presence }\end{array}$ & & $\begin{array}{l}\text { esponsibility } \\
\text { for } \\
\text { ompletion of } \\
\text { Work }\end{array}$ & $\begin{array}{c}\text { Compliance } \\
\text { with } \\
\text { Obligations } \\
\text { and } \\
\text { Prohibitions }\end{array}$ \\
\hline 1 & $\begin{array}{l}\text { Epih } \\
\text { Gunaeti }\end{array}$ & 87 & & 46 & 38 \\
\hline 2 & Sapri & 74 & & 60 & 45 \\
\hline 3 & $\begin{array}{l}\text { Farhan } \\
\text { Syadidan }\end{array}$ & 77 & & 80 & 37 \\
\hline 4 & $\begin{array}{l}\text { Deddy } \\
\text { Ramdani }\end{array}$ & 69 & & 76 & 85 \\
\hline 5 & $\begin{array}{l}\text { Abdul } \\
\text { Rahman }\end{array}$ & 80 & & 74 & 74 \\
\hline \multicolumn{6}{|c|}{ Table 7 Alternative Criteria } \\
\hline & & & \multicolumn{3}{|c|}{ Criteria } \\
\hline No & \multicolumn{2}{|c|}{ Alternatives } & C1 & C2 & C3 \\
\hline 1 & & & 60 & 20 & 20 \\
\hline 2 & & & 20 & 40 & 20 \\
\hline 3 & & & 40 & 60 & 20 \\
\hline 4 & & & 20 & 60 & 80 \\
\hline 5 & & & 60 & 40 & 40 \\
\hline
\end{tabular}

Furthermore, normalizing each alternative value on each attribute by calculating the work rating value, as follows:

$$
r=\left[\begin{array}{lll}
60 & 20 & 20 \\
20 & 40 & 20 \\
40 & 60 & 20 \\
20 & 60 & 80 \\
60 & 40 & 40
\end{array}\right]
$$

Normalizing Matrices:

$\begin{array}{lll}r_{1,1}=1 & r_{2,1}=0,33 & r_{3,1}=0,25 \\ r_{1,2}=0,33 & r_{2,2}=0,67 & r_{3,2}=0,25 \\ r_{1,3}=0,67 & r_{2,3}=1 & r_{3,3}=0,25 \\ r_{1,4}=0,33 & r_{2,4}=1 & r_{3,4}=1 \\ r_{1,5}=1 & r_{2,5}=0,67 & r_{3,5}=0,5\end{array}$


JURNAL RISET INFORMATIKA

Vol. 2, No. 3 June 2020

Normalization results are as follows:

$\boldsymbol{r}=\left[\begin{array}{ccc}1 & 0,33 & 0,25 \\ 0,33 & 0,67 & 0,25 \\ 0,67 & 1 & 0,25 \\ 0,33 & 1 & 1 \\ 1 & 0,67 & 0,5\end{array}\right]$

Then calculate the value of preference weights for each alternative, the results obtained are as follows:

$V_{1}=\mathbf{0 , 5 8} ; V_{2}=\mathbf{0}, \mathbf{4 1} ; V_{3}=\mathbf{0}, 64 ; V_{4}=\mathbf{0 , 7 3}$

$V_{5}=\mathbf{0 , 7 5}$

Ranking results obtained:

$V_{5}=\mathbf{0 , 7 5}$

$V_{4}=\mathbf{0 , 7 3}$

$V_{3}=\mathbf{0}, \mathbf{6 4}$

$V_{1}=\mathbf{0 , 5 8}$

$V_{2}=\mathbf{0}, \mathbf{4 1}$

Last is to rank, the results obtained are as follows:

Table 8 Ranking

\begin{tabular}{clc}
\hline No & \multicolumn{1}{c}{ Alternatives } & V \\
\hline 1 & Abdul Rahman & 0,75 \\
2 & Deddy Ramdani & 0,73 \\
3 & Epih Gunaeti & 0,58 \\
4 & Farhan Syadidan & 0,64 \\
5 & Sapri & 0,41 \\
\hline
\end{tabular}

Based on Table 8 above shows the results of ranking V5 is the best PPSU.

\section{A. Use Case Diagram}

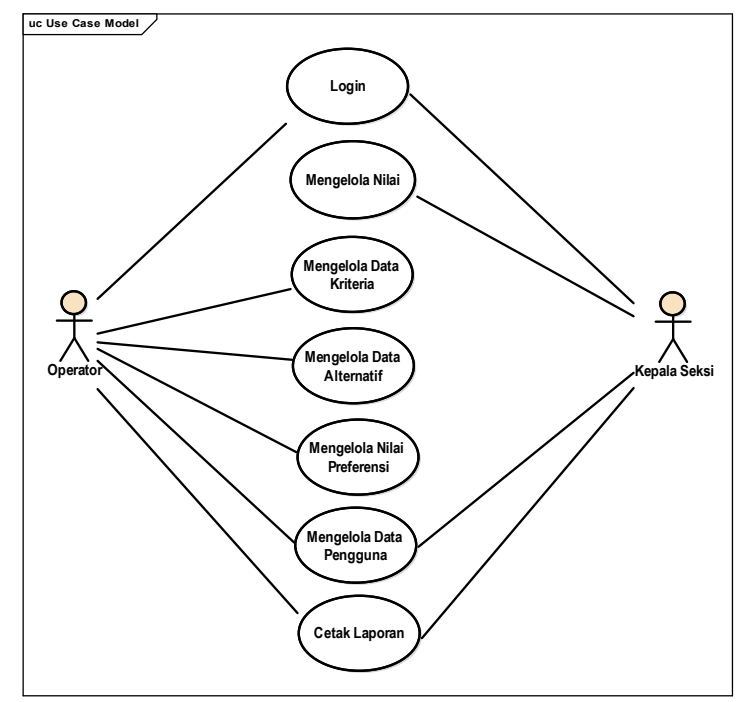

Figure 1 Use Case Diagram
P-ISSN: 2656-1743 |E-ISSN: 2656-1735

DOI: https://doi.org/10.34288/jri.v2i3.146

Explanation of figure 2 that the Operator can manage criteria data, alternative data, data on the value of prevalence, user data, and print reports. Whereas the Section Chief can manage user data, manage grades, and print reports.

\section{B. Initial Display Interface}

1. Login page

(1). RELURABAN MUNJUL

Figure 3 Login page

Figure 3 above is the appearance of the login page of the PPSU Job Performance Evaluation application.

2. Home page

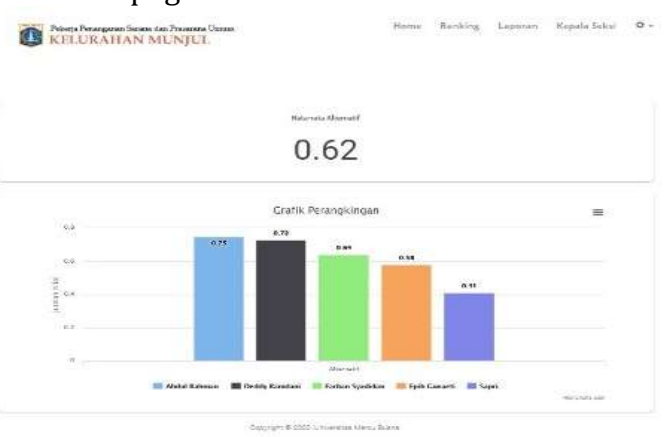

Figure 4 Home page

Figure 4 above is the appearance of the home page that shows a graph of individual values and the average value of PPSU.

3. Section Head Profile Page

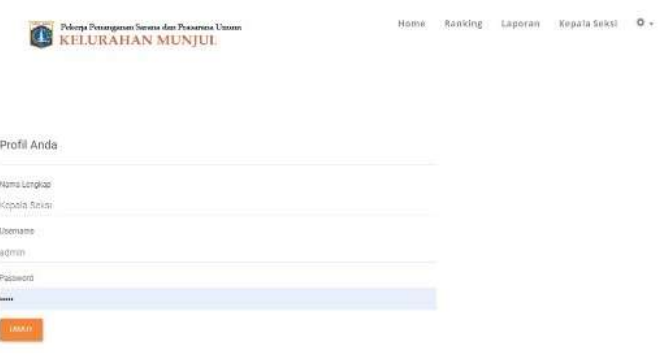

Figure 5 Section Head Profile Page 
Figure 5 above is the Section Head page display, on the menu, the Section Head can update his profile data.

4. PPSU Job Performance Evaluation Page

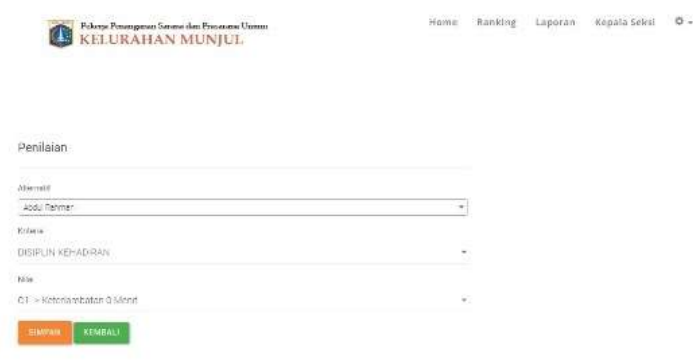

Figure 6 PPSU Job Performance Evaluation Page

Figure 6 above is the PPSU Performance Evaluation page, the Section Head chooses alternative data, criteria, and grades.

5. Operator Profile Page
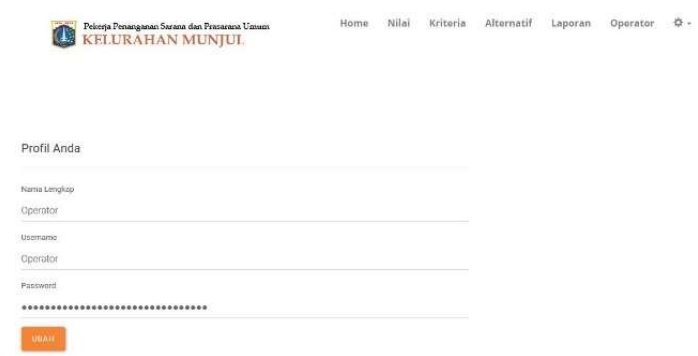

Figure 7 Operator Profile Page

Figure 7 above is the Operator page display, on the menu, the Operator can update their profile data.

6. Value Preferences page

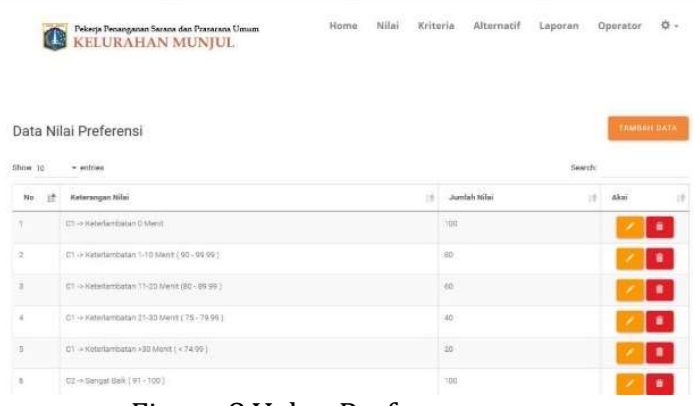

Figure 8 Value Preferences page

Figure 8 above is a view of the Value Preferences page, the operator can update the Value data on this page.
7. Criteria Page
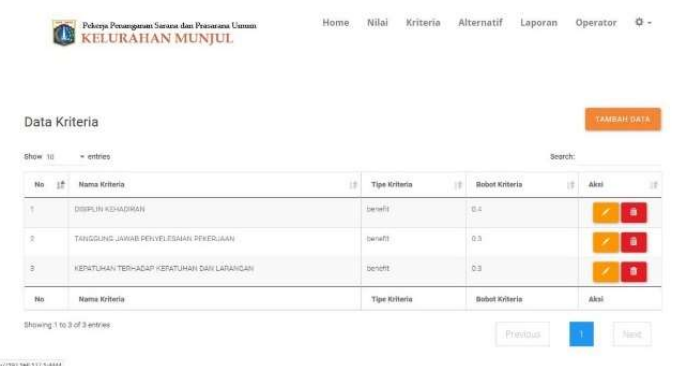

Figure 9 Criteria page

Figure 9 above is a view of the Criteria page, the operator can update the Criteria data on this page.

8. Alternative Page
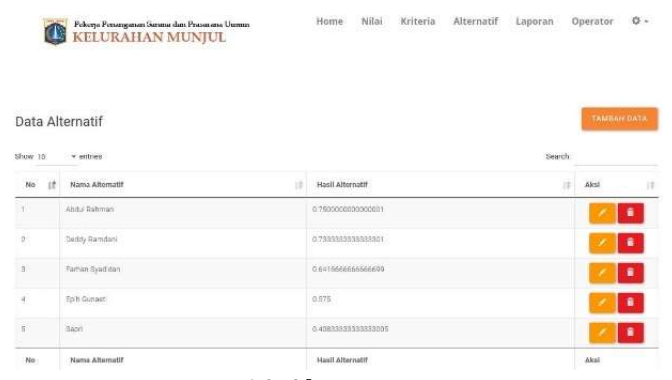

Figure 10 Alternative Pages

Figure 10 above is an Alternative page display, the operator can update the Alternative data on this page.

9. Report Page

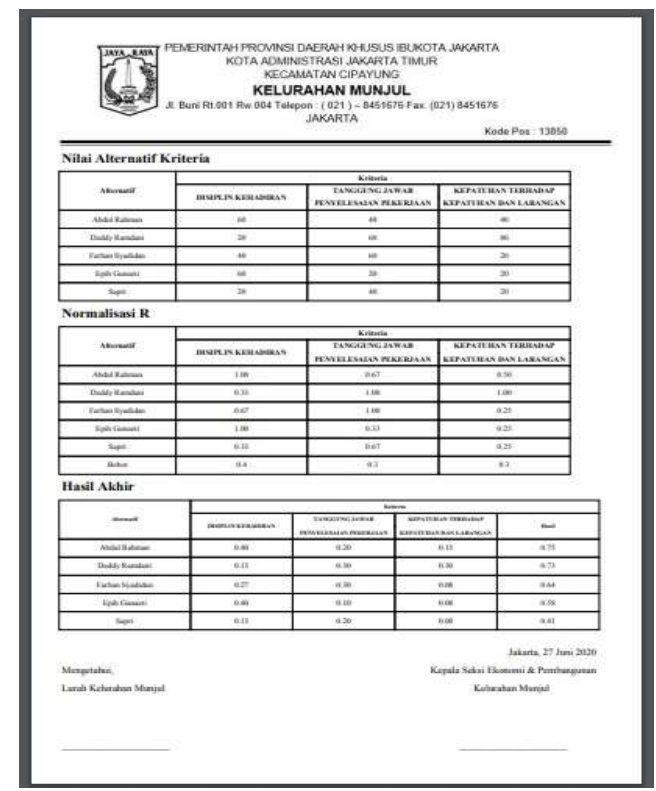

Figure 11 Report Page 
Figure 11 above is the report page display, Head of Section and Operators can see the results of the assessment and assessment report.

\section{CONCLUSIONS AND SUGGESTIONS}

Based on the results of the study, it can be concluded that the PPSU Job Performance Evaluation application using the SAW method can assist leaders in determining the best PPSU based on predetermined criteria, where the PPSU with the highest score will get the highest rating value, this application can provide value to the PPSU that the Head of Economics and Development provides value objectively, the application can motivate PPSU to compete to improve work performance, this application can be alternative decision support for PPSU recruitment every year. It is hoped that further system development can be more interesting and interesting.

\section{REFERENCE}

Agus, I., Marisa, F., \& Wijaya, I. D. (2017). Sistem Pendukung Keputusan Penerimaan Dan Penilaian Karyawan Warehouse Dengan Aplikasi Web. JOINTECS OJournal of Information Technology and Computer Science), 2(1). https://doi.org/10.31328/jointecs.v2i1.413

Agustini, F., \& Ariska, E. R. (2019). PENERAPAN METODE SIMPLE ADDITIVE WEIGHTING (SAW) DENGAN MODEL FUZZY MODEL ATTRIBUTE DECISION MAKING (FMADM) PENILAIAN KINERJA KARYAWAN DTPEDULI. Jurnal Techno Nusa Mandiri, 16(1), 21-28. https://doi.org/10.33480/techno.v16i1.107

Baswedan, A. (2019). Peraturan Gubernur DKI Jakarta No 125 Tahun 2019 Tentang Perubahan Kedua Atas Peraturan gubernur No 212 Tahun 2016 Tentang Pedoman Pengelolaan Jasa Orang Perorangan.

Bintoro, B., \& Daryanto, D. (2017). Manajemen Penilaian Kinerja Karyawan (1st ed.). Penerbit Gava Media.

Frieyadie, F. (2018). METODE AHP SEBAGAI PENUNJANG KEPUTUSAN UNTUK PENILAIAN KINERJA KERJA KARYAWAN SPBU. Jurnal Techno Nusa Mandiri, 15(1), 6368.
https://doi.org/10.33480/TECHNO.V15I1.60

Kurniawan, D., Dan, W., \& Chandra Aditya, R. (2015). Sistem Pendukung Keputusan Pemilihan Dosen Berprestasi Menggunakan Metode Simple Additive Weighting di Lingkungan Universitas Lampung. Jurnal Komputasi, 3(2), 90-98. https://doi.org/10.23960\%2Fkomputasi.v3i 2.1137

Latif, L. A., Jamil, M., \& Abbas, S. H. (2018). Buku Ajar: Sistem Pendukung Keputusan Teori dan Implementasi. Deepublish Publisher.

Moch.Ali, R., \& Chandra, A. (2018). Perancangan Sistem Pendukung Keputusan Penilaian Kinerja Dosen Berbasis Web Menggunakan Metode SAW Pada Stmik-Im Bandung. Jurnal Informasi, $X(2)$, 44-77. http://ojs.stmikim.ac.id/index.php/INFORMASI/article/view $/ 28$

Nofriansyah, D., \& Defit, S. (2017). Multi Criteria Decision Making (MCDM) Pada Pendukung Keputusan (Cetakan Pe). Penerbit Deefpublish.

Putri, D. A. (2018). PENERAPAN METODE FUZZY SAW SEBAGAI PENDUKUNG KEPUTUSAN PENGANGKATAN KARYAWAN TETAP PERUSAHAAN. Jurnal Techno Nusa Mandiri, 15(1), 31-36. https://doi.org/10.33480/TECHNO.V15I1.55

Rihastuti, S., Rosyidi, A., \& Setiyawan, M. (2019). PENERAPAN METODE SAW UNTUK MERANCANG SISTEM PENILAIAN KINERJA KARYAWAN STMIK AMIKOM SURAKARTA. SENSITIf: Seminar Nasional Sistem Informasi Dan Teknologi Informasi, 881-888. https://ejurnal.dipanegara.ac.id/index.php/s ensitif/article/view/454

Setya, B., \& Kom, M. (1994). Sistem Pendukung Keputusan Menggunakan Metode Simple Additive Weighting Pada Ptpn Xii Perkebunan Malangsari. 10(1110651133), 497-504.

Sukanto, P. S. (2018). Sistem Pendukung Keputusan Penilaian Kinerja Karyawan Pt Harjamukti Jaya Mandiri Menggunakan Metode Simple Additive Weighting. JATISI (Jurnal Teknik Informatika Dan Sistem Informasi), 5(1), 109-118. https://doi.org/10.35957/jatisi.v5i1.121 
Widyastuti, T., \& Kurnianda, N. R. (2019). Perancangan Sistem Informasi Pengajuan Pinjaman Berbasis Web Menggunakan Metode Simple Additive Weighting. Jurnal Pilar Nusa Mandiri, 15(2), 219-226. https://doi.org/10.33480/pilar.v15i2.716 